\title{
Membongkar Makna Pertunjukan Tari Sang Hyang Dedari Di Puri Saren Agung Ubud, Bali Pada Era Global
}

\author{
Ni Made Ruastiti \\ Fakultas Seni Pertunjukan, Institut Seni Indonesia Denpasar \\ E-mail penulis : nimaderuastiti@gmail.com.
}

Tujuan penelitian ini dilakukan untuk memahami makna Tari Sang Hyang Dedari yang kini sering disajikan dalam konteks pariwisata di Puri Saren Agung Ubud, Bali. Padahal Tari Sang Hyang Dedari merupakan sebuah tari upacara untuk memohon keselamatan bagi masyarakat setempat. Sebagai sebuah tari upacara, Tari Sang Hyang Dedari semestinya hanya disajikan di pura dalam konteks upacara saja. Namun kenyataannya di Puri Saren Agung Ubud berbeda. Untuk itu, penelitian yang berlokasi di Puri Saren Agung Ubud ini akan mengkaji permasalahan tentang: (1) mengapa Puri Saren Agung Ubud menyajikan Tari Sang Hyang Dedari dalam konteks pariwisata?; (2) bagaimana mereka menyajikan?; dan (3) bagaimana Puri Saren Agung Ubud memaknai Tari Sang Hyang Dedari tersebut?.

Penelitian ini dilakukan dengan menggunakan metode penelitian kualitatif dalam perspektif cultural studies yang dianalisis dengan teori dekonstruksi, teori estetika postmodern, teori praktik, dan teori relasi kuasa pengetahuan.

Hasil penelitian menunjukan bahwa: (1) Puri Saren Agung Ubud menyajikan Tari Sang Hyang Dedari dalam konteks pariwisata karena dilatari adanya peluang pasar yakni berkembangnya industri pariwisata di Ubud serta adanya potensi kesenian masyarakat yang memadai untuk menampilkan seni pertunjukan pariwisata; (2) Puri Saren Agung Ubud menyajikan Tari Sang Hyang Dedari untuk pariwisata dalam bentuk tari kreasi baru pelegongan yang konsep penciptaannya merupakan pengembangan bentuk estetika pertunjukan Tari Sang Hyang Dedari untuk upacara; (3) Puri Saren Agung Ubud memaknai pertunjukan Tari Sang Hyang Dedari dalam konteks pariwisata terebut sebagai sebuah kreativitas seni, produk pariwisata bernilai ekonomi, sebagai pengikat relasi sosial masyarakat yang berimplikasi pada pelestarian seni pertunjukan tradisional di daerah tersebut pada era global.

Kata kunci: Membongkar makna, Pertunjukan Tari Sang Hyang Dedari, Objek Wisata Puri Saren Agung Ubud, Bali.

\section{Deconstructing The Meaning Of Sanghyang Dedari Dance Performance At Puri Saren Agung Ubud, Bali In Globalization Era}

This research is aimed at comprehending the meaning of Sang Hyang Dedari Dance which is frequently performed the context of tourism at Puri (Palace) Saren Agung Ubud Bali. In fact, the Sang Hyang Dedari dance was comprehended by the local people as a dance to asking for blessing and safety. As a ceremonypurposed dance, this dance should be performed in the temple the context of ceremony only. However, it comes to a different reality at Puri Saren Agung. Therefore, this research that taken place at Puri Saren Agung would analyze the problems about: (1) why does the Puri Saren Agung perform the Sang Hyang Dedari Dance under the tourism context? (2) how do they perform? (3) How does the Puri Saren Agung contextualize the dance?

This research applies the qualitative method under the cultural studies perspective within the deconstructive theory, postmodern esthetic theory, theory of practice, and the knowledge-power relation theory. 
The result shows that (1) The Puri (Palace) Saren Agung Ubud Gianyar Bali performs the Sang Hyang Dedari Dance under tourism context as it led by the market opportunity of the tourism development in Ubud, as well as supported by the local people art potential in performing this dance for tourism purposes, (2) Puri Saren Agung performs the Sang Hyang Dedari Dance for tourism as a new creation dance of pelegongan which the concept was taken from the development of its esthetic form of Sang Hyang Dedari Dance of ceremony; (3) Puri Saren Agung contextualizes the Sang Hyang Dedari Dance under its tourism context as an art creativity of a tourism product which has economical values, meaning as social-relation bound among surrounding society which yield on the preservation of traditional art performance in this region during the globalization era.

Keywords : Deconstructing meaning, Sang Hyang Dedari Dance Performance, Tourism object of Puri Saren Agung Ubud, Bali.

Proses Review : 19 April - 4 Mei 2017, Dinyatakan Lolos : 8 Mei 2017

\section{PENDAHULUAN}

Sang Hyang Dedari merupakan sebuah tari tradisional Bali yang dimaknai sebagai tari upacara untuk memohon keselamatan bagi masyarakat setempat. Sebagai sebuah tari upacara, Tari Sang Hyang Dedari memiliki konsep pertunjukan tersendiri yang sifatnya sakral. Hal itu dapat dilihat dari bentuk pertunjukan, konteks, lokasi, waktu, pelaku, proses pertunjukan, dan lain sebagainya yang keseluruhannya itu dimaknai sebagai sebuah tari upacara.

Tari Sang Hyang Dedari yang ditarikan oleh dua orang penari anak-anak ini diiringi oleh nyanyiannyanyian kidung dan olah vokal cak. Sebelum menari kedua penari diusung memasuki area pura kemudian disucikan di hadapan pelinggih, bangunan pura dengan upacara ritual khusus antara lain melakukan persembahyangan dilanjutkan dengan penyucian diri penari melalui proses pedudusan, asap bara api diiringi oleh nyanyian-nyanyian kidung dan olah vokal cak.

Proses pedudusan yang diiringi nyanyian kidung itu dimulai dari suara lirih dengan tempo pelan. Selanjutnya tempo iringan musik tari upacara tersebut terus meningkat semakin cepat dengan suara vokal yang semakin meninggi. Para penari itupun merespon irama gending tersebut dengan menggoyang-goyangkan kepalanya dari tempo pelan semakin cepat hingga kedua penari itupun terjatuh tidak sadarkan diri. Dalam keadaan tidak sadarkan diri itu, kedua penari tersebut kemudian bangun dan menari menggunakan kipas dengan mata terpejam.

Dalam kondisi tidak sadarkan diri para penari itu terus menari, meliuk-liukan tubuhnya dalam kondisi mata terpejam diiringi dengan nyanyian kidung yang dinyanyikan dalam tempo yang semakin cepat dengan suara yang semakin keras. Setelah penari mengakhiri tariannya, para penari Tari Sang Hyang Dedari yang diyakini raganya tengah dirasuki Dewa tersebut berujar kepada warga masyarakat yang melaksanakan upacara tersebut tentang kesan-kesan pelaksanaan upacara dan sesaji yang telah dipersembahkan kepada para Dewa penguasa jagat raya yang berstana di pura tersebut. Pantja (1994: 28) menyatakan bahwa pertunjukan Tari Sang Hyang Dedari dalam konteks upacara dilaksanakan setahun sekali di Pura Kahyangan Tiga di Desa Celuk Gianyar.

Namun seiring berjalannya waktu, belakangan ini tampak Tari Sang Hyang Dedari sering disajikan dalam konteks pariwisata di Puri Saren Agung Ubud. Hal ini tentu menimbulkan berbagai pertanyaan. Sebagai sebuah tari upacara, Tari Sang Hyang Dedari semestinya hanya disajikan di pura dalam konteks upacara saja. Namun kenyataannya kini di Puri Saren Agung Ubud tampak berbeda. Tari Sang Hyang Dedari disajikan secara regular sebagai sebuah komuditas pariwisata.

Sebagai daerah tujuan wisata, Bali mengembangkan industri pariwisatanya berdasarkan Perda nomor 3 Tahun 1974 yang direvisi menjadi Perda 
nomor 3 tahun 1991. Kebijakan itu menegaskan bahwa Bali sebagai daerah tujuan wisata diharapkan mengembangkan daerahnya berdasarkan visi pembangunan yang berwawasan budaya. Setiap industrialisasi pariwisatanya diharapkan bernuansakan budaya Bali.

Berdasarkan kebijakan tersebut, industri pariwisata Bali mengalami kemajuan sangat pesat, baik ragam produk yang ditawarkan maupun meningkatnya jumlah wisatawan yang datang ke daerah ini. Hal itu tidak terlepas dari perhatian pemerintah terhadap pengembangan industri pariwisata di daerah ini. Berbagai fasilitas publik penunjang pariwisatapun menjamur di Bali antara lain seperti hotel-hotel, tempat-tempat penginapan, restaurant, tempat pertunjukan, sarana transportasi dan lain sebagainya. Berbagai fasilitas pariwisata berstandar internasional pun tampak bermunculan di Bali. Salah satu daerah yang sangat pesat perkembangan industri pariwisatanya di Bali adalah Desa Ubud.

Ubud merupakan sebuah desa wisata yang sangat ramai dikunjungi wisatawan mancanegara, tempat para pelukis dunia mencari inspirasi. Keindahan alam dan tradisi kehidupan masyarakat Ubud banyak dilirik wisatawan sejak tahun 1900-an. Hal ini erat kaitannya dengan keberadaan dua pelukis kenamaan yaitu Walter Spies dan Rodulf Bonnet yang memperkenalkan Ubud melalui dunia seni lukis. Ramainya wisatawan berkunjung ke Ubud mendorong maraknya berbagai produk wisata menarik tumbuh di desa tersebut. Seperti misalnya produk wisata alam Rafting di desa Sayan Ubud. Masyarakat di daerah tersebut mengunakan potensi alamnya yakni sungai Ayung yang melintang di desa tersebut sebagai tempat arung-jeram. Selain itu masyarakat di Desa Padang Tegal, Ubud juga mengembangkan kebun binatang keranya menjadi objek wisata Monkey Forest.

Selain banyak terdapat objek wisata alam, di Ubud juga banyak terdapat objek wisata puri. Beberapa puri dikembangkan menjadi objek wisata budaya antara lain Puri Saren Agung, Puri Kantor, Puri Lotus, Pura Batukaru, dan lain sebagainya. Pada siang hari, puri-puri itu ramai dikunjungi wisatawan mancanegara untuk melihat-lihat arsitektur puri yang dikenal sangat unik. Sementara di malam hari puri itu ramai dikunjungi wisatawan untuk menonton seni pertunjukan. Masing-masing puri itu menampilkan seni pertunjukan pariwisata yang khas dan menarik. Tetapi, di antara seni-seni pertunjukan yang disajikan dalam konteks pariwisata di Ubud terdapat pertunjukan Tari Sang Hyang Dedari. Berkembangnya industri pariwisata secara tidak langsung telah mempengaruhi perkembangan seni pertunjukan Bali. Perkembangan industri pariwisata yang begitu pesat ini dianggap sebagai peluang dan tantangan bagi masyarakat setempat untuk terus berkreativitas dalam seni pertunjukan (Ruastiti, 2010).

Pesatnya perkembangan industri pariwisata di Ubud mendorong pihak Puri Saren Agung Ubud untuk mengembangkan purinya sebagai objek wisata. Keberadaan puri yang strategis di kawasan daerah pariwisata Ubud membuat banyak wisatawan datang berkunjung ke puri tersebut. Cerita yang disebarluaskan oleh para wisatawan yang pernah mengunjungi puri ini mendorong keingintahuan wisatawan lainnya untuk melihat secara langsung bagaimana struktur dan lingkungan Puri Saren. Dengan sikap yang ramah dan terbuka, pihak puri menyambut setiap wisatawan yang datang berkunjung ke Puri Saren Agung Ubud.

Sebagai sebuah objek wisata, Puri Saren Agung Ubud memiliki daya tarik tersendiri yang tidak bisa dilepaskan dari berbagai faktor yang melatar belakangi, terutama berkaitan dengan potensi budaya sebagai daya tarik, attractions antara lain meliputi arsitektur, benda-benda kuno, tari-tarian, dan hospitality, keramah-tamahan mereka dalam menerima wisatawan. Spilane (1994 : 63) mengatakan bahwa selain objeknya menarik sebuah destination akan ramai dikunjungi wisatawan jika mereka disambut dengan sikap yang ramah.

Puri Saren Agug Ubud yang arsitekturnya dikenal sangat unik tersebut hingga kini tampak masih terawat dan asri. Keasrian arsitektur puri hingga kini terus dijaga masyarakatnya sebagai identitas raja Ubud. Sekalipun sistem feodal semakin memudar pasca-kejayaan kerajaan namun bukan berarti rasa hormat rakyat kepada raja ataupun keturunannya menjadi luntur.

Sebagai sebuah destinasi wisata, Puri Saren Agung Ubud memiliki benda-benda kuno peninggalan jaman kerajaan yang terkenal memiliki nilai estetika tinggi. Selain sebagai repositori budaya, 
Puri Saren Agung Ubud juga digunakan sebagai pusat berkesenian bagi warga masyarakat setempat. Puri berperan sebagai pelindung utama kesenian yang terdapat di daerah tersebut. Banyaknya benda-benda kuno tersimpan di puri ini membuat Puri Saren Agung Ubud ini ramai dikunjungi wisatawan mancanegara di siang hari. Sementara pada malam hari, puri ini ramai dikunjungi wisatawan untuk memonton berbagai jenis pertunjukan tradisional yang ditampilkan warga masyarakat di daerah tersebut. Hampir setiap hari Puri Saren Agung Ubud menampilkan seni pertunjukan tari untuk wisatawan.

Namun belakangan ini tampak sering dipentaskan Tari Sang Hyang Dedari di puri tersebut. Padahal secara ideal, Tari Sang Hyang Dedari dimaknai sebagai sebuah tari upacara untuk memohon keselamatan bagi masyarakat setempat. Sebagai sebuah tari upacara, Tari Sang Hyang Dedari semestinya hanya disajikan di pura dalam konteks upacara saja. Namun kenyataannya di Puri Saren Agung Ubud berbeda.

Berdasarkan uraian tersebut, maka dalam penelitian yang berlokasi di Puri Saren Agung Ubud ini akan dikaji permasalahan tentang: (1) mengapa pihak Puri Saren Agung Ubud menyajikan Tari Sang Hyang Dedari untuk pariwisata?; (2) bagaimana mereka menyajikan?; dan (3) bagaimana pihak Puri Saren Agung Ubud memaknai Tari Sang Hyang Dedari dalam konteks pariwisata tersebut?.

\section{METODE PENELITIAN}

Metode penelitian yang digunakan untuk mengkaji fenomena pertunjukan Tari Sang Hyang Dedari di Puri Saren Agung Ubud dalam konteks pariwisata tersebut adalah metode penelitian kualitatif yang sumber datanya berasal dari sumber data primer yakni pertunjukan Tari Sang Hyang Dedari di Puri Saren Agung Ubud serta para informan terkait pertunjukan tersebut. Seluruh data penelitian ini diperoleh dari observasi, wawancara dan studi kepustakaan.

Data primer, berupa informasi dan hal-hal terkait dengan tahapan pertunjukan Tari Sang Hyang Dedari diperoleh langsung di lapangan dengan menonton pertunjukan tari itu di Puri Saren Agung Ubud. Sementara, data berupa informasi diperoleh melalui wawancara langsung di lapangan dengan para informan terkait yang dipilih berdasarkan teknik purposif sampling. Beberapa informan yang dimaksud antara lain para penari, para penabuh, pelatih tari, pelatih tabuh, ketua sanggar, pihak puri dan masyarakat di sekitar tempat pertunjukan yang mengetahui keberadaan tarian tersebut.

Tahapan observasi mulai dilakukan sebelum wawancara dilakukan dengan para informan. Untuk menyimak fenomena ini secara total kemudian dilakukan wawancara dengan para informan terkait antara lain dengan informan kunci yakni pihak puri, pelatih tari, pelatih tabuh pertunjukan tersebut. Tindakan iu dilakukan setelah bertemu dengan kepala desa selaku informan pangkal. Berdasarkan informasi yang diberikan oleh kepala desa setempat kemudian dilakukan wawancara dengan pihak puri, para penari, penabuh, dan seterusnya hingga informasi tentang keberadaan tari itu dianggap cukup. Penambahan informan untuk melengkapi data yang masih kurang ini dilakukan dengan teknik snowball sampling.

Untuk melengkapi data penelitian ini dilakukan studi kepustakaan yang diperoleh dari hasil-hasil penelitian yang telah dihasilkan oleh para peneliti sebelumnya. Seluruh data yang telah dikumpulkan ini kemudian dianalisis secara kritis dengan menggunakan teori dekonstruksi, teori estetika postmodern, teori praktik, dan teori relasi kuasa pengetahuan.

\section{HASIL DAN PEMBAHASAN}

\section{Makna Tari Sang Hyang Dedari Di Puri Saren Agung Ubud}

Makna merupakan bagian dari semantik dan tuturan. Pengertian dari makna sendiri sangatlah beragam. Makna selalu menyatu pada kalimat maupun tuturan warganya secara kolektif. Artinya bahwa makna sebagai bagian dari hidup terbentuk dari pengalaman tradisi, historis beserta hubungan relasi sosialnya. Makna bersifat intangibel yang kemudian memberikan nilai lebih pada tindakan masyarakatnya.

Sebagaimana masyarakat di Ubud dalam memaknai Tari Sang Hyang Dedari yang disajikan sebagai seni pertunjukan pariwisata di Puri Saren Agung Ubud, yang memediasi dan membina bakat 
berkesenian masyarakat setempat melalui industri pariwisata.

Secara dekonstruktif, pementasan Tari Sang Hyang Dedari merupakan praktek estetis, sebagai respon atas peluang pariwisata yang berkembang di Ubud. Proses kontruksi tersebut kemudian berdampak terhadap bentukan citra positif bagi Puri Saren Ubud sebagai sentral budaya di desa tersebut. Pada fase ini, tidak saja muncul keindahan sebagai sebuah makna tunggal dari aktivitas berkesenian masyarakat setempat melainkan juga muncul sejumlah makna terkait dengan keberadaan Tari Sang Hyang Dedari dalam konteks pariwisata di Puri Saren Agung Ubud. Adapun makna yang dimaksud antara lain sebagai berikut.

\section{Makna Estetika}

Keindahan pementasan Tari Sang Hyang Dedari di Ubud mengandung makna estetika. Dalam pementasan Tari Sang Hyang Dedari menampilkan banyak unsur keindahan, antara lain tampak dari ragam gerak yang ditampilkan secara harmonis, serasi dan menyatu dengan musik iringan tarinya. Sebagaimana diungkapkan Vickers (1989: 117) bahwa tari Bali pada dasarnya dilandasi nilai-nilai agama Hindu sebagai persembahan karya seni yang suci kepada para Dewa.

Gerakan Tari Sang Hyang Dedari memiliki kekhasan tersendiri, begitu pula tata rias rambut, busana dan properti yang dipergunakan sangat serasi. Tari Sang Hyang Dedari memiliki ragam gerak antara lain: gerak nyregseg, miles, sogok, ngukel, ngotag, nyalud, nabdap gelung, ngelog, ngekes, ngegol, ngeseh, tanjek, nyalud, sledet, nyegut, nyregseg. Ragam gerak tari tersebut mengandung makna keindahan dan keseimbangan.

Pementasan Tari Sang Hyang Dedari menjadi meriah berkat iringan dari gamelan gong Semarandhana. Keberadaan gamelan memperkuat suasana pertunjukan, mempertegas aksen dan tempo gerak tari. Keberadaan gending yang dimainkan penabuh tampak mampu memperkuat nuansa keindahan dari setiap dinamika pertunjukan Tari Sang Hyang Dedari tersebut.

Keindahan Tari Sang Hyang Dedari tercermin dari komposisi pertunjukan tarian yang menyatu dengan tata rias busana tarian tersebut.
Tata rias busana Tari Sang Hyang Dedari yang terdiri atas kain dasar berwarna putih diprada kuning, selembar kain dikenakan melilit pada tubuh penari dari pinggang sampai mata kaki, dipadukan dengan baju berwarna dasar putih diprada kuning.

Pada bagian pinggang dililitkan sabuk prada berwarna kuning dengan motif bun-bunan untuk menutupi badan hingga di atas pinggul. Pada bagian dada penari digunakan lamak dari kulit sapi, pada bahu dipasang simping dari kulit sapi. Sementara pada bagian dada dililitkan tutup dada dari kain beludru yang dihiasi sulaman dan manik-manik. Sementara pada pergelangan tangan dipasang gelang kana dari kulit sapi yang dilapisi prada emas, dan pada leher penari dipasang badong dari kulit sapi yang dilapisi prada emas. Sebagaimana tampak pada gambar di bawah ini.

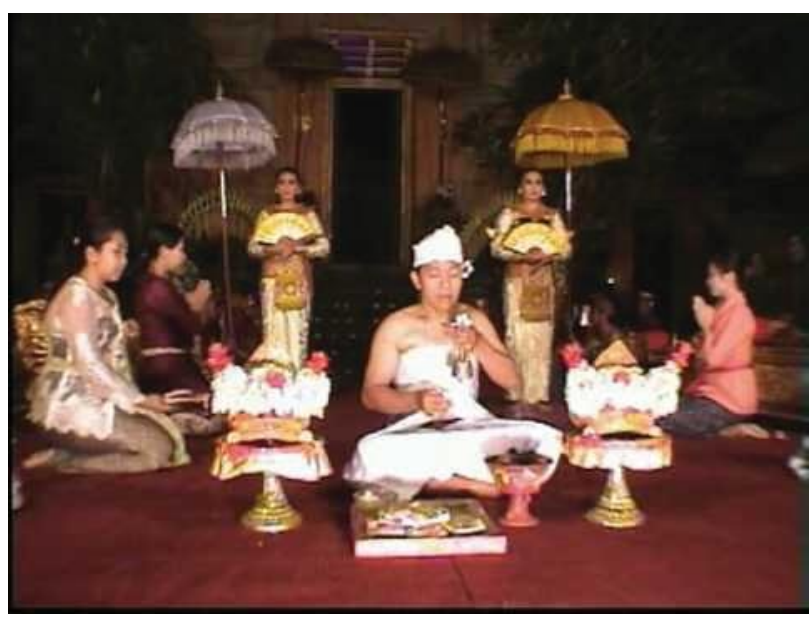

Gambar 1. Bagian Awal Pertunjukan Tari SangHyang Dedari di Puri Saren Agung Ubud Dok. Ruastiti, 2016.

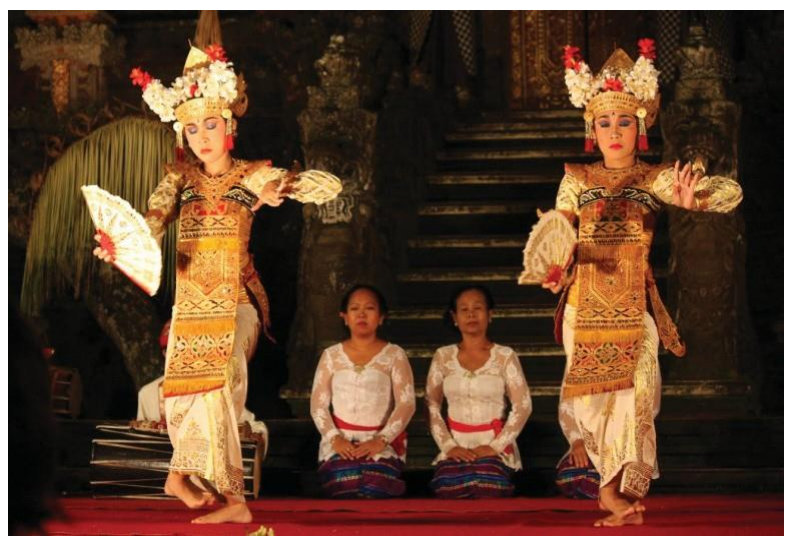

Gambar 2. Bagian Inti Pertunjukan Tari SangHyang Dedari di Puri Saren Agung Ubud Dok. Ruastiti, 2016. 
Pertunjukan Tari Sang Hyang Dedari ini juga menggunakan properti berupa kipas berwarna putih dihiasi prada emas. Untuk mahkota, penari menggunakan gelungan legong yang dihiasi bunga kamboja sebagai simbol kesucian. Sementara pada bagian pinggul digunakan ampok-ampok dari kulit sapi yang dihiasi prada emas.

Untuk tata rias wajah, Tari Sang Hyang Dedari menggunakan bedak dasar berwarna coklat, bedak tabur berwarna kemerah-merahan, merah pipi, eye shadow berwarna kuning, merah, biru, coklat. Sementara pada kelopak mata digunakan eye liner berwarna hitam, pensil alis berwarna hitam, dan lipstik merah yang bermakna keindahan dari sinar cahaya.

Makna keindahan yang tercermin dalam tata rias busana Tari Sang Hyang Dedari yang mencakup makna keseimbangan, harmoni, dan saling melengkapi. Makna keseimbangan juga terungkap dalam gerak tari, pada pola lantai Tari Legong Sang Hyang Dedari.

Koreografi Tari Sang Hyang Dedari yang disusun berdasarkan konsep seni pertunjukan pariwisata merupakan wujud konkret dari gagasan yang beorientasi pada pasar. Oleh sebab itu performa Tari Legong Sang Hyang Dedari yang menggambarkan persembahan dapat dengan mudah dipahami oleh wisatawan yang berlatarkan budaya lain. Ketertarikan wisatawan terhadap Tari Legong Sang Hyang Dedari di puri Saren Agung Ubud mendorong para seniman di daerah itu untuk terus berinovasi menciptakan gerakan-gerakan tari yang merupakan simulakra dari gerakan aslinya. Sebagaimana dinyatakan oleh Baudrillard bahwa kegiatan duplikasi dilakukan untuk menciptakan sesuatu yang mendekati bentuk aslinya (Baudrillard, 1988).

Beberapa komponen pertunjukan Tari Sang Hyang Dedari tampak dikembangkan dengan konsep estetika posmodern antara lain konten, konteks, ruang dan waktu penyajian pertunjukan tersebut. Secara sepintas tampak sama dengan pertunjukan tari aslinya (sakral) namun jika diamati secara seksama pertunjukan tersebut sesungguhnya berbeda.

\section{Makna Ekonomi}

Banyaknya kunjungan wisatawan ke Ubud merupa kan penyebab utama muncul dan berkembangnya Tari Sang Hyang Dedari di Puri Saren Ubud, Gianyar. Tampilan pertunjukan Tari Sang Hyang Dedari yang disajikan dalam konsep seni pertunjukan pariwisata tampak mampu menarik minat wisatawan untuk menonton secara berulang-ulang. Kehadiran wisatawan untuk menyaksikan pertunjukan itu secara berulang-ulang menimbulkan semangat para seniman (sekaa) Tari Sang Hyang Dedari untuk terus meningkatkan kualitas pertunjukannya agar wisatawan (konsumen) tidak merasa kecewa membayar mahal.

Karl Marx dan Simmel dalam (Turner, 1992: 115138) mengatakan bahwa ekonomi uang yang didasarkan atas spirit memperoleh keuntungan dapat menimbulkan gejala komodifikasi. Komodifikasi merupakan suatu cara langsung dan sengaja (dengan penuh kesadaran) sebagai sebuah komoditas (Barker, 1999: 17). Komoditas adalah sesuatu yang sengaja disiapkan untuk dijual di pasar.

Pasar bebas yang sering disebut dengan ekonomi global turut memberi peluang bagi seniman di Puri Saren Ubud, Gianyar dalam berkesenian. Pertunjukan Tari Sang Hyang Dedari sebagai potensi yang perlu dipelihara dan dikembangkan sebagai komoditi pariwisata. Pertunjukan Tari Sang Hyang Dedari dirancang untuk meningkatkan taraf ekonomi masyarakat di Ubud.

Keberlangsungan Tari Sang Hyang Dedari sebagai seni pertunjukan pariwisata baru di Ubud selama ini tampak telah dapat meningkatkan kesejahteraan hidup pelaku di Ubud. Dengan menjadi penari Tari Sang Hyang Dedari mereka dapat memperoleh tambahan masukan finansial. Kesempatan pelaku tampil dalam pertunjukan Sang Hyang Dedari itu dianggap telah dapat menjadi sumber ekonomi tambahan bagi kebahagiaan keluarga mereka. Hal itu menandakan bahwa pertujukan Tari Sang Hyang Dedari diperlukan untuk peningkatan kualitas hidupnya saat ini. Pertunjukan Tari Sang Hyang Dedari yang dilaksanakan secara reguler untuk wisatawan di Ubud bermakna ekonomi bagi masyarakat sekaligus memajukan nama Puri Saren Ubud.

\section{Makna Sosial}

Pertunjukan Tari Sang Hyang Dedari memiliki makna sosial bagi masyarakat di Ubud terutama 
dalam merawat sikap gotong royong bagi kesatuan sosial mereka. Hal itu dapat dilihat dari setiap pelaksanaan pertunjukan Tari Sang Hyang Dedari yang dilaksanakan masyarakat di Ubud.

Secara regular masyarakat di Desa Ubud tampak terlibat secara aktif dalam kegiatan kepariwisataan di Puri Saren Agung Ubud. Seringnya mereka pentas di puri membuat hubungan antar para pelaku menjadi semakin intens. Belum lagi, dukungan dari para pengurus, penata rias busana yang terlibat dalam pertunjukan tersebut. Pertunjukan Tari Sang Hyang Dedari yang banyak dikagumi wisatawan itu secara tidak langsung dapat berimplikasi pada penguatan hubungan relasi sosial di antara mereka. Begitu pula tentang hubungan patron klien dengan puri. Mekanisme semacam ini merupakan proses yang sangat diperlukan dalam menjaga solidaritas sosial masyarakat pada era global.

Solidaritas sosial merupakan sebuah modal sosial bagi kesatuan sosial. Sujana (1994:49-63) mengemukakan bahwa proses kerjasama, gotong-royong disertai sikap toleransi sangat diperlukan dalam mempersiapkan sebuah pementasan. Makna solidaritas yang tampak dalam pementasan Tari Sang Hyang Dedari meliputi keterlibatan hubungan antar masyarakat yang harmonis dalam kebersamaannya menyelesaikan setiap acara pertunjukan. Untuk menyukseskan setiap pertunjukannya, masyarakat di Desa Ubud seperti para penari, penata rias busana dan lain sebagainya mesti bekerjasama melakukan kegiatan tersebut. Mulai dari mempersiapan pertunjukan hingga mementaskan Tari Sang Hyang Dedari itu diperlukan kerjasama yang baik. Oleh sebab itu rutinitas pelaksanaan pertunjukan itu dapat membuat hubungan komunikasi antarpelaku semakin erat.

Keberlanjutan pertunjukan itu dapat dimaknai sebagai kesepahaman kolektif antar mereka. Keberlangsungan kegiatan pertunjukan ini secara tidak langsung akan dapat menguatkan kesatuan sosial di antara mereka yang ditunjukkan melalui rasa saling menghargai di antara mereka. Solidaritas sosial yang tercipta melalui pelaksanaan pertunjukan Tari Sang Hyang Dedari dalam konteks pariwisata ini secara tidak langsung dapat dipahami sebagai media bagi penguatan ikatan relasi sosial dan hubungan patroon-client puri dengan masyarakat di sekitarnya pada era global.

\section{Makna Budaya}

Pementasan Tari Sang Hyang Dedari di Puri Saren Agung Ubud dalam konteks pariwisata dapat dipahami memiliki makna budaya. Masyarakat Ubud yang menyajikan Tari Sang Hyang Dedari dalam konteks pariwisata tersebut dapat dimengerti karena mereka ingin keseniannya lestari. Tari Sang Hyang Dedari yang diciptakan berdasarkan inspirasi dari Tari Sang Hyang Dedari untuk upacara tersebut dianggap memiliki makna penting karena merupakan elemental dari budaya masyarakat setempat. Jika mereka sering menampilkan tarian tersebut diyakini akan dapat mengkaver kesatuan sosial antar mereka pada era global yang kini cenderung sibuk dengan kegiatannya masing-masing.

Agar seluruh unsur pertunjukan terinternalisasi secara baik pada pelaku maka penyelenggaraan pementasan Tari Sang Hyang Dedari yang telah berlangsung secara berkesinambungan itu melibatkan peran masyarakat. Kegiatan tersebut dirancang pihak puri guna memperkuat proses penerusan nilai-nilai budaya masyarakat setempat. Para penari, penabuh, dan lain sebagainya tentu secara tidak langsung mereka ikut dalam proses penerusan nilai-nilai budaya tradisional daerah tersebut secara berkelanjutan. Melalui aktivitas kepariwisataan ini masyarakat setempat tampak secara tidak langsung terajarkan pendidikan estetika, etika berupa sopansantun, dan lain sebagainya. Hal ini dianggap sangat menunjang kehidupan berbudaya di desa tersebut tetap lestari pada era global ini.

Setiap unsur kebudayaan mempunyai makna penting yang sangat berpengaruh bagi masyarakat yang bersangkutan. Sebagai contoh misalnya pada saat mereka belajar menari, mementaskan Tari Sang Hyang Dedari untuk pariwisata maka para penari, penabuh dan lain sebagainya mendapat pendidikan informal tentang etika, agama, seni, budaya dan lain sebagainya. Dengan semakin rutinnya para penari, penabuh itu pentas tentu secara tidak langsung akan berimplikasi bagi reflek keterampilan menarinya sebagai penguatan karakter dan identitas budaya masyarakat setempat. Para pihak yang terkait dengan pertunjukan Tari Sang Hyang Dedari yang telah menguasai materi tari secara tidak langsung akan dapat menguntungkan bagi penerusan nilainilai budaya masyarakat setempat. Hal itu dapat dilihat dari sikap mereka dalam menyiapkan dan menyajikan tari tersebut. 
Orientasi budaya masyarakat Desa Ubud dalam melaksanakan ritunitas pertunjukan itu secara tidak disadari akan sesuai dengan nilai-nilai dan sistem budaya masyarakat setempat. Hal itu dapat dilihat ketika mereka menyajikan Tari Sang Hyang Dedari. Sebagai sebuah seni pertunjukan pariwisata, Tari Sang Hyang Dedari yang disajikan dalam konteks pariwisata di Puri Saren Agung Ubud tampak memperoleh dukungan dari masyarakatnya. Hal itu disebabkan karena komponen-komponen serta cara penyajiannya dianggap sesuai dengan nilai-nilai, norma budaya masyarakat setempat.

Suatu tradisi budaya yang dianggap adiluhung akan selalu dipergunakan oleh kelompok masyarakat tersebut dalam menata kehidupannya. Sebagaimana pandangan masyarakat Ubud terhadap Tari Sang Hyang Dedari yang dianggap bermanfaat sebagai penunjang kebutuhan hidup dan pelestari budaya mereka pada era global ini. Hal itu dapat dilihat dari sikap para pelaku pertunjukan tari tersebut yang merupakan warga masyarakat Desa Ubud selalu berusaha menjaga, mempertahankan tari tersebut karena dianggap mampu memediasi warga dalam penerusan nilai-nilai budaya lokal kepada para generasinya, bahkan kepada warga lainnya yang menonton. Dengan demikian, pementasan Tari Sang Hyang Dedari sangat bermakna dalam enkulturasi budaya di Desa Ubud pada era global.

\section{Implikasi Pertunjukan Tari Sang Hyang Dedari Untuk Pariwisata di Ubud}

Totalitas pertunjukan Tari Sang Hyang Dedari di Puri Saren Agung Ubud dapat berimplikasi bagi penguatan internalisasi nilai-nilai agama, sosial dan kultural di desa tersebut. Tari Sang Hyang Dedari yang disajikan sebagai produk seni pertunjukan unggulan pariwisata di Puri Saren Agung Ubud tersebut telah berimplikasi pada penguatan identitas budaya masyarakat di Ubud. Dengan mengkaji implikasi pertunjukan Tari Sang Hyang Dedari di Puri Saren Agung Ubud dapat dipahami tentang kemajuan budaya masyarakat di Ubud saat ini.

Meninjau pendapat Langer dalam Danesi (2010:233) bahwa manusia berkesenian tidaklah sebagai potongan terpisah, melainkan merupakan sebuah pengalaman emosional yang tidak terlepas dari kehidupnya. Begitu pula sebaliknya, jika diamati pertunjukan tersebut dapat dipahami bahwa begitu kuatnya stimulus budaya global sehingga mampu menciptakan perubahan pada masyarakat tersebut.

Sebagaimana terciptanya pertunjukan Tari Sang Hyang Dedari untuk pariwisata di Puri Saren Ubud tampak bahwa kegiatan kepariwisataan berbasis seni pertunjukan itu telah berimplikasi pada kebertahanan kondisi ekonomi, sosial, citra kewibawaan Puri Saren Agung berikut animo masyarakatnya dalam melestarikan seni pertunjukan tradisionalnya pada era global ini.

Keindahan pertunjukan Tari Sang Hyang Dedari telah berimplikasi sosial bagi setiap pelaku Tari Sang Hyang Dedari di Ubud. Volkelt dalam Gie (1996: 78) mengemukakan bahwa keindahan alamiah atau keindahan seni dapat menjadi sumber keberhargaan dari dirinya sendiri. Keindahan memungkinkan mereka mengubah emosinya menjadi lebih lega sehingga merasakan kepuasan dan kesenangan yang selanjutnya dapat membuat kehidupannya menjadi lebih baik dan bergairah. Artinya bahwa pertunjukan Tari Sang Hyang Dedari yang terlahir dari pengalaman keindahan masyarakat pendukungnya itu telah dapat membuat masyarakat di Desa Ubud menjadi lebaih baik melalui media pertunjukan Tari Sang Hyang Dedari untuk pariwisata di Puri Saren Agung Ubud. Begitupula para penari maupun penabuhnya yang terlibat langsung dalam pertunjukan tersebut. Secara tidak langsung merasa senang, bangga sebagai pelaku Tari Sang Hyang Dedari itu. Hal itu disebabkan karena dengan menampilkan Tari Sang Hyang Dedari mereka mendapat penghargaan, apresiasi dari wisatawan. Terlebih dengan terlibatnya mereka sebagai pelaku pertunjukan tersebut mereka memperoleh masukan finansial yang memadai untuk memenuhi kebutuhan hidupnya. Malinowski dalam Nasikun (2000: 12) mengatakan bahwa fungsi dari setiap unsur pada sebuah struktur diperuntukan untuk memenuhi kebutuhan hidup masyarakatnya.

Sebagai sebuah karya seni, Tari Sang Hyang Dedari dapat dimaknai fungsional sebagai pemenuhan kebutuhan psikologis dan sosiokultural masyarakat setempat. Terselenggaranya pertunjukan Tari Sang Hyang Dedari sebagai sebuah karya seni baru bernuansa kearifan lokal Bali dapat terintegrasi bagi keberlangsungan estetika seni tari tradisional di Desa Ubud pada era global. 
Hal itu dapat dilihat dari totalitas penyajian pertunjukan Tari Sang Hyang Dedari yang secara tidak langsung berimplikasi pada kepuasan para pihak terkait baik pelaku maupun penontonpertunjukan. Setiap saat mereka dapat berkumpul bersama mempertunjukan Tari Sang Hyang Dedari tersebut.

Dalam kaitan itu, Tari Sang Hyang Dedari dapat dipahami sebagai pembangun dan penguat identitas diri maupun identitas kelompok masyarakat tersebut. Oleh karena itu, pertunjukan Tari Sang Hyang Dedari dianggap sebagai bagian dari perjuangan sosial Puri Saren Agung Ubud melalui media pariwisata. Dengan menampilkan Tari Sang Hyang Dedari dalam konteks pariwisata, puri yang didukug masyarakat di sekitarnya dianggap turut menjaga kelestarian seni pertunjukan tradisional daerah tersebut.

Nilai-nilai budaya direvitalisasi melalui ungkapanungkapan gerak simbolis yang dituangkan dalam pertunjukan Tari Sang Hyang Dedari untuk memantapkan internalisasi budaya di tengah kehidupan masyarakatnya yang telah maju. Internalisasi nilainilai budaya yang dilakukan melalui media seni pertunjukan pariwisata ini selanjutnya akan berimplikasi pada kokohnya relasi sosial, karakter budaya, kesatuan masyarakat setempat di tengah dinamika permasalahan hidup pada era global.

Hal itu dapat dilihat dari kontribusi yang diberikan terhadap para elite lokal selaku pembina seni. Jika dicermati dalam dimensi sosial tampak bahwa pertunjukan Tari Sang Hyang Dedari tersebut dapat berimplikasi pada empat pokok: Pertama, penanggungjawab artistik. Kedua, suksesi terhadap sosialisasi seniman di tengah masyarakat penontonnya. Ketiga, berimplikasi bagi penguatan relasi sosial, khususnya penguatan hubungan patroo-client dalam sistem feodal. Keempat, popularitas kelompok pertunjukan Tari Sang Hyang Dedari yang berimplikasi bagi kebanggaan setiap individu sebagai pelaku pertunjukan tersebut di masyarakat.

Pemaknaan keindahan suatu karya seni mesti dilakukan sesuai dengan konsepsi budaya setempat. Hal itu disebabkan karena karya seni tersebut merupakan produk budaya lokal yang diciptakan berdasarkan sistem kebudayaan masyarakat tersebut. Sebagaimana pertunjukan Tari Sang Hyang Dedari yang diciptakan berdasarkan konsep budaya di Ubud, merupakan genealogi masyarakat setempat yang dominan beragama Hindu. Dengan menonton pertunjukan Tari Sang Hyang Dedari tidak hanya dapat dipahami nilai estetika tarian tersebut, namun juga dapat dipahami nilai-nilai sosial-religius masyarakatnya. Tari Sang Hyang Dedari yang kini menjadi seni pertunjukan pariwisata Puri Saren Ubud telah dapat memvisualisasikan estetika sekaligus keunggulan karakter budaya masyarakat setempat.

Melalui pertunjukan Tari Sang Hyang Dedari dalam konteks pariwisata di Puri Saren Agung Ubud dapat dipahami nilai-nilai tentang hakekat hidup masyarakat setempat. Artinya, melalui pertunjukan tari tersebut penonton dapat memperoleh gambaran identitas budaya lokal yang khas dalam rangkaian sebuah pertunjukan pariwisata. Unsur-unsur kearifan lokal yang terintegrasi dalam estetika pertunjukan tari kreasi baru palegongan itu dapat memberikan citra harmoni kehidupan masyarakat setempat kepada penonton.

Tari Sang Hyang Dedari yang mentransmisikan sejumlah unsur budaya lokal dalam konteks pariwisata itu secara tidak langsung berimplikasi bagi pelestarian seni budaya lokal pada era global.

\section{SIMPULAN}

Berdasarkan uraian di atas dapat disimpulkan bahwa : (1) Puri Saren Agung Ubud menyajikan Tari Sang Hyang Dedari dalam konteks pariwisata karena dilatari adanya peluang pasar yakni berkembangnya industri pariwisata di Ubud serta adanya potensi kesenian masyarakat setempat yang memadai untuk menampilkan seni pertunjukan pariwisata; (2) Puri Saren Agung Ubud menyajikan Tari Sang Hyang Dedari untuk pariwisata dalam bentuk tari kreasi baru pelegongan dengan struktur pertunjukan terdiri atas : pengawit, pengawak, pengecet, dan pekaad, yang konsep penciptaannya terinspirasi dari pertunjukan Tari Sang Hyang Dedari untuk upacara; (3) Puri Saren Agung Ubud memaknai pertunjukan Tari Sang Hyang Dedari dalam konteks pariwisata tersebut sebagai sebuah kreativitas seni, produk pariwisata bernilai ekonomi, sebagai pengikat relasi sosial masyarakat yang berimplikasi pada pelestarian seni pertunjukan tradisional di daerah tersebut pada era global. 


\section{DAFTAR RUJUKAN}

Bandem, I Made dan Frederik Eugene de Boer. 1973. Kaja dan Kelod: Balinese Dance in Trasnsition. Kuala Lumpur: Oxford University Press.

Baudrillard, Jean. 1988. Simulacra and Simulation dalam Mark Poster (ed), Selected Writings. Stanford : Stanford Universty Press.

Barker, Chris. 2005. Cultural Studies : Teori dan Praktik. Terjemahan Cultural Studies: Theory and Practice. Yogyakarta : BENTANG PT. Bentang Pusaka.

Daulay, Asrul (ed.). 2011. Pendidikan dan Pemberdayaan Masyarakat. Medan: USU Press.

Dewi, Trisna. 2014. Kajian Bentuk dan Fungsi Tari Rejang Seregan di Desa Kayubihi, Bangli (skripsi). Denpasar : ISI.

Dibia, Wayan. 1985. 'Odalan Of Hindu Bali; A Religius Festival, a Social Occasion and a Theatrical Event' dalam Asian Thetatre Journal Volume 2. Honolulu : University of Hawaii Press.

Hardiman, Budi F. 2003. Kritik Ideologi : Menyingkap Pertautan dan Kepentingan Bersama Jurgen Habermas. Yogyakarta : Kanisius.

Koentjaraningrat.1993. Ritus Peralihan di Indonesia. Jakarta : Balai Pustaka.

Putra, Ambalika. 1986. Tari Rejang Renteng di Banjar Jangu Karangasem (Skripsi). Denpasar : STSI.

Hasan, Sandi Suwardi. 2011. Pengantar Cultural Studies. Sambilegi : Ar-Ruzz Media.

Pantja, I Made. 1994. Upacara Sang Hyang Dedari di Desa Celuk Kecamatan Sukawati Kabupaten Gianyar Propinsi Bali. Tesis Program Studi Antropologi. Jakarta: Program Pascasarjana Universitas Indonesia.

Ruastiti, Ni Made. 2010. Seni Pertunjukan Pariwisata Bali. Yogyakarta: Kanisius.
Sumadia. 2011. Pementasan Tari Rejang Renteng Dalam Rangka Piodalan Agung di Pura Desa Pakraman Sukasada, Kecamatan Sukasada, Buleleng (skripsi). Denpasar : ISI.

Sumantri, Zaimar. 2001. "Ideologi dalam Pariwara" dalam Ida Sundari Husen dan Rahayu Hidayat (penyunting). Merentas Ranah, Bahasa, Semiotika dan Budaya. Yogyakarta: Bentang.

Spillane, James J. 1994. Pariwisata Indonesia : Siasat Ekonomi dan Rekayasa Kebudayaan. Yogyakarta: Kanisius.

Turner, B. S. 1992. Max Weber : From History to Modernity. London: Routledge.

Wijayanto, Eko. 2012. Genealogi Kebudayaan. Jakarta : Salemba Humatika.

Yanti, Suari. 2009. Tari Rejang Lilit Dalam Upacara Dewa Yadnya Di Pura Khayangan Tiga, Desa Adat Mundeh, Tabanan (Skripsi). Denpasar: ISI.

Vickers, Adrian. 1989. Bali A Paradise Created. Berkeley: Periplus Editions. 